\title{
A new species of Telmatobufo (Schmidt 1852) (Anura, Calyptocephalellidae) from a remnant of the Maulino Forest, central Chile
}

\section{Una nueva especie de Telmatobufo (Schmidt 1852) (Anura, Calyptocephalellidae) en un remanente de bosque Maulino, Chile Central}

\author{
César C. Cuevas ${ }^{1 *}$ \\ ${ }^{1}$ Instituto de Zoología, Facultad de Ciencias, Universidad Austral de Chile, Casilla 567, Valdivia, Chile. \\ *E-mail: ccuevas@uach.cl
}

\begin{abstract}
A new species, Telmatobufo ignotus, from the Reserva Nacional Los Queules, Cauquenes Province, central Chile is described herein. The new taxon is hypothesized based on a new combination of adult, larval, and chromosomal characters. The new species present the more septentrional distribution on the coastal range and a very restrictive distribution area compared to its congeners; because of this, taxonomic and conservation comments are discussed and advanced.
\end{abstract}

KeYwords: New species, anura, Telmatobufo, morphology, chromosomes, central Chile.

\section{RESUMEN}

Se describe una nueva especie, Telmatobufo ignotus, de la reserva Nacional Los Queules en Chile Central. El nuevo taxón se hipotetiza en base a una nueva combinación de caracteres del adulto, larvas y cromosomas. La nueva especie al contrario de sus congéneres, presenta la distribución más septentrional en la Cordillera de la Costa y un área de distribución muy restringida: por esto, se discuten algunos aspectos sobre su taxonomía y conservación.

Palabras clave: Nueva especie, anura, Telmatobufo, morfología, cromosomas, Chile Central.

\section{INTRODUCTION}

The genus Telmatobufo Schmidt 1952 is a rare ancient group of South American frogs containing up to day three valid allopatric species, occurring all of them in a wide geographical range, but each one in a different forest ecosystem throughout the Chilean territory (Formas et al. 2001). Thus, T. venustus (Philippi 1899), is endemic of the Andean hygrophyte forest of central Chile (ca. $35^{\circ} 28^{\prime}-37^{\circ}$ $47^{~ S)}$ ); T. bullocki Schmidt 1952, microendemic in the forest of the Nahuelbuta coastal range (ca. $37^{\circ}-38^{\circ} \mathrm{S}$ ); and $T$. australis Formas 1972 has been documented distributed in the temperate forest of Nothofagus in Southern Chile. This is the only species occurring in both, Andes and coastal range (ca. $41^{\circ}-39^{\circ} \mathrm{S}$ ).
Since the description of this genus (Schmidt 1952), only 20 adults' specimens of the three species have been recovered from Cabrerias, Llancahue, Cerro Pûschel (T. australis); Parque Nacional Nahuelbuta, Rucapehuen (T. bullocki); Altos de Vilches (T. venustus) (see Formas et al. 2001; Ortiz \& Diaz-Páez 2006) and therefore they are considered as "rare" species (Formas 2005; Ortiz \& Ibarra-Vidal 2005). However, despite of the paucity of both, biological material and listing localities; precious knowledge concerning adult and larval morphology, cytogenetics, taxonomy, systematic and some ecological notes about these frogs (see Péfaur 1971; Formas 1972; Diaz et al. 1983; Formas 1988; Formas \& Cuevas 2000; Núñez \& Formas 2000; Formas et al. 2001), has been published. Nevertheless, many aspects of its reproductive biology, ethology and biogeography are still unknown, and because of increasing threat of extinction that amphibians suffer worldwide today (mainly due to the loss of habitat) (Beebee \& Griffiths 2005; IUCN 2008), perhaps 
we will never achieve that knowledge.

In this context, there is a need for freshly taxonomic knowledge related to Chilean frogs to get an accurate species inventories and basic biological and ecological information, given the scarce number of species and the high degree of endemism and vulnerability that characterizes the anurans of the forest ecosystem of South America (Formas 1979, Bustamante \& Simonetti 2005, Cuevas \& Cifuentes 2009). During successive fieldwork campaigns conducted between summer 2007 and autumn 2009, in the National Reserve Los Queules (coastal range in central Chile), 28 frog's tadpoles, a juvenile and an adult male of the genus Telmatobufo were collected. This finding was very striking given the zoogeographic connotation of this genus (San Mauro et al. 2005; Frost 2009). Thus, bearing in mind that a morphological species is a hypothesis based on a new combination of characters (Dayrat 2005); we hypothesized that the new sample and locality belong to a new species of Telmatobufo, based on adult and larval characteristics. This new species is named encompassed with ecological notes, life history traits and chromosome attributes herein. Finally, the new record of Telmatobufo is discussed and assessed in view of bio-geographical hypothesis related with gondwanic frogs, and the possible negative consequences of the habitat degradation on his viability given the larval strategies of the Telmatobufo species.

\section{MATERIAL AND METHODS}

Both, adult specimen and tadpole samples were stored in Alcohol $70 \%$ and formaldehyde $10 \%$, respectively. Abbreviations used in the measurements of the adult specimens are SVL (snout-vent length), HL (head length), HW (head width), IDi (internareal distance), ED (eye distance), ThL (thigh length), TL (tibia length), FL (foot length) following Wiens (1993). Formulae for toes webbing are those of Savage and Heyer (1967), as modified by Myers \& Duellman (1982). Measurements were made with a digital calliper to the nearest $0.01 \mathrm{~mm}$. The tadpoles were staged according to Gosner (1960), and their morphology was characterized following Altig (2007) and Altig \& Johnson (1989). Measurements included total length (TL), body length (BL), body width (BW), maximum tail width (MTW), snout eye distance (SED), eye distance (Edi), and oral disc width (ODW). To reduce bias, all the measurements were done by the first author.

To characterize metaphasic chromosomes, a section of the tail of each tadpole was excised and submerged in Colchicine $0.05 \%$ for $2 \mathrm{~h}$. The fragments were treated with distilled water during $30 \mathrm{~m}$, fixed in acetic alcohol (1:3), and then placed in $45 \%$ acetic acid. Metaphasic plates were obtained by squashing fragments of tail epithelium and then dipping them in liquid nitrogen (Cuevas \& Formas 1996). Chromosomes were stained with acetic Orcein $50 \%$ to determine the diploid number and the position of secondary constrictions (Schmid 1978). The best five metaphasic plates were selected to determine the relative length of chromosomes (Bogart 1970). Centromeric ratio and type of chromosome were determined according to Green \& Sessions (1991). Photograph of metaphasic chromosome plates and specimens (adult and tadpoles) were deposited in the Amphibian Collection of the Instituto de Zoología, Universidad Austral de Chile (IZUA).

\section{RESULTS}

Telmatobufo ignotus sp. nov.

Holotype: IZUA 3542, one adult male of Telmatobufo with well developed sexual secondary attributes collected by José Nùñez, César Cuevas and Felipe Rabanal, on May of 2009 (Fig. 1).

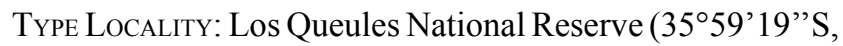
$72^{\circ} 41^{\prime} 25^{\prime \prime} \mathrm{W}$; at 187 m.a.s.l.), a remnant of the Maulino forest in central Chile; $22 \mathrm{~km} \mathrm{NW}, 15$ minutes by road from Curanipe city), Cauquenes Province, Western slopes of the coastal range (Fig. 2).

Paratypes: A group of twenty eight tadpoles (lot IZUA 3543). Same data as holotype.

Diagnosis: Telmatobufo ignotus sp. nov. can be distinguished from its congeners by the following combination of characters: 1) maximum snout-vent length in male (SVL) 70 $\mathrm{mm}, 2$ ) snout slightly truncated in dorsal and lateral profile, 3) Soft yellow spots with orange tints colour over both eyes, joined by a more orange inter-ocular spot, 4) Dorsal part of the arms (near to the body) yellowish in colour and orange in the forearms, 5) two median ovoid's parotids glandules, longitudinally located and, smaller than ocular globes, 6) iris rounded, brilliant bronze-yellowish with reticulations, 7) minutes dark spines (20) present under the parotids, 8) flanks and dorsum with moderate amount of warts, which are bigger in the vertebral line region, 9) Inner palmar tubercle oval and enlarged, bigger than the outer, 10) four to five small vomerine teeth on each side, in a prominent elevated patches behind the level of the choanae, 11) dorsum of legs smooth and unbarred, 12) tips of fingers and toes whitish with rounded points, 13) toes very thin, long with well developed webbing present, 14) mountain stream tadpole with two teeth rows on the upper labium, 15) $2 n=26$ (all biarmed) chromosomes), $\mathrm{FN}=52,16) \mathrm{SC}$ on pair 5. 
Comparison: Telmatobufo ignotus differs clearly from $T$. australis and T. venustus in dorsum colour patterns (grey with yellowish longitudinal lines in $T$. australis, dark with orange spots in T. venustus, and slightly brown with cooperish hints in T. ignotus n. sp.). It also differs with $T$. bullocki in the size of the parotids (median sized, smaller than ocular globe in T. ignotus; larger sized, bigger than ocular globes in T. bullocki), in the form and colour of a distinctive mark over the head (slightly orange-yellowish spots in form over both ocular globes in T. ignotus (Fig.1); clearly yellowish highlighted, transversally located over and between the ocular globes in T. bullocki). Telmatobufo ignotus present a higher amount, but smaller sized warts in the flanks and dorsum than T. bullocki, and also differs from this species in vomerine teeth number; 4-5 in T. ignotus, 6-7

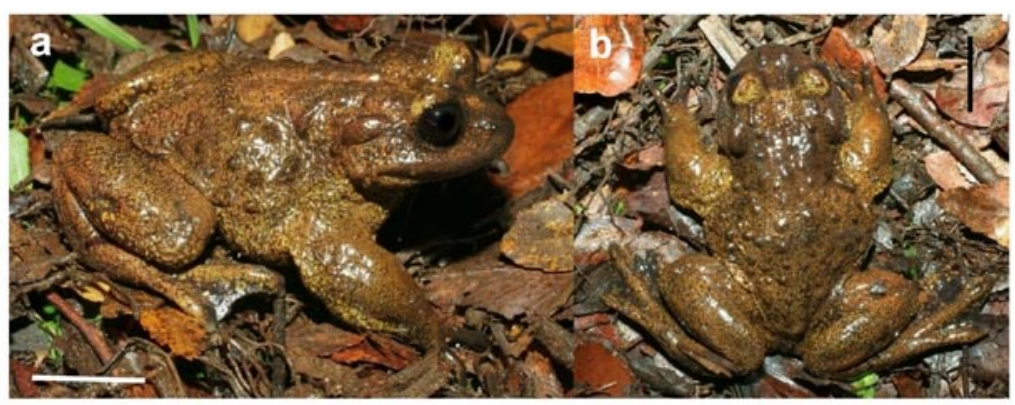

Figure 1. Adult male of Telmatobufo ignotus from Los Queules. (a) Lateral view; Bar $=2 \mathrm{~cm}$, (b) Dorsal view; Bar $=1.7 \mathrm{~cm}$.

Figura 1. Macho adulto de Telmatobufo ignotus de Los Queules. (a) Vista lateral; Barra = $2 \mathrm{~cm}$, (b) Vista dorsal; Barra $=1.7 \mathrm{~cm}$.

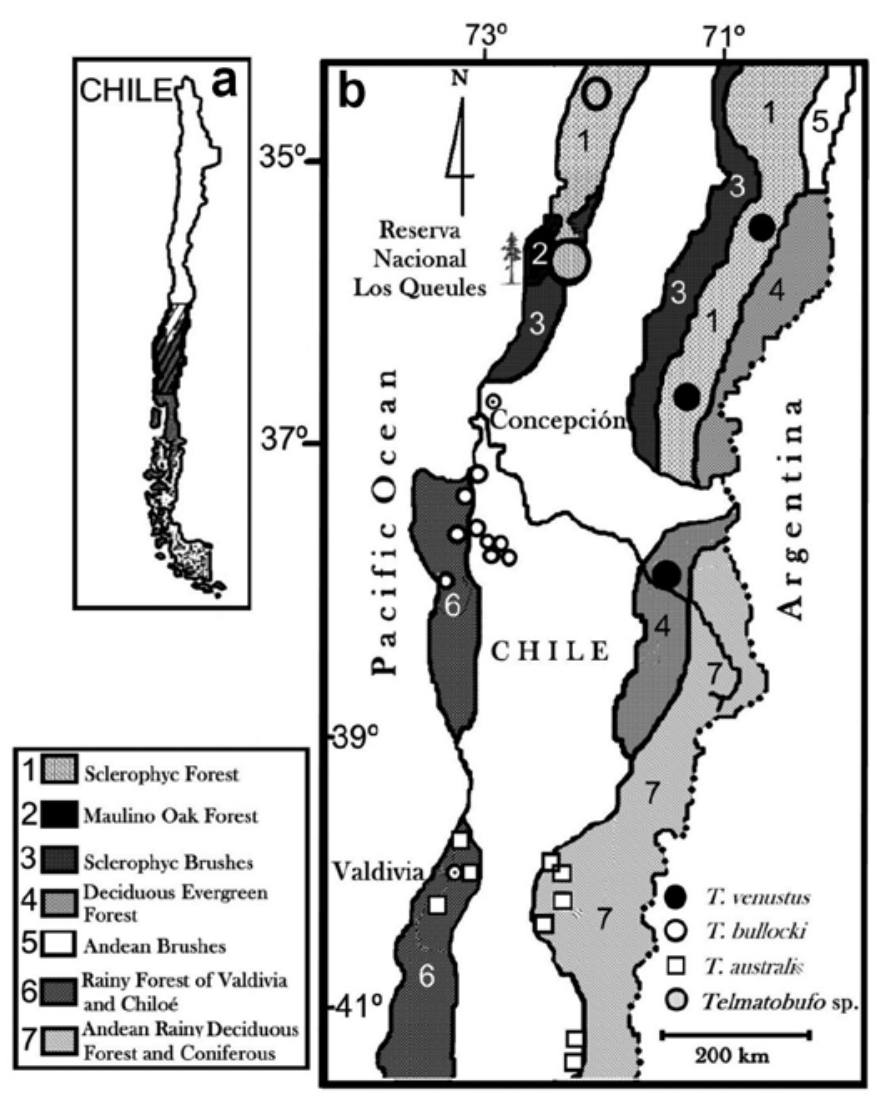

FIGURE 2. Maps of Chile: (a) showing study area in crossed off., (b) distributional geographic dots of Telmatobufo species in Central South of Chile and Los Queules locality with grey circle. Forest classification is explained in the inferior left frame.

Figura 2. Mapas de Chile: (a) mostrando el área de estudio en achurado, (b) puntos de distribución geográfica de las especies de Telmatobufo en la zona centro y sur de Chile y Los Queules en circulo gris. En recuadro inferior izquierda se explica la clasificación de los bosques. 
in T. bullocki (Schmidt 1952, Péfaur 1971).

When we compare tadpoles in similar Gosner (1960) stage of the four Telmatobufo species (see table 2), those of T. ignotus (stage 26) are clearly larger than those of $T$. australis (stage 29), T. bullocki (26) and T. venustus (27). Tadpoles of $T$. ignotus are markedly larger sized than those of $T$. australis, T. bullocki and T. venustus (Table 2). Furthermore, they differ in pattern of colouring from the other Telmatobufo species. The tadpoles from Los Queules present a broad variety of colours that varies between dark blue, brown with gray spot, and brown with orange spot. Tadpoles known from $T$. bullocki from Nahuelbuta Range were always gray in colour with the belly whitish and translucent (Formas et al. 2001). From the chromosomal point of view $T$. ignotus present a formula $7 \mathrm{~m}+4 \mathrm{sm}+2 \mathrm{st}$ (Table 3 ) differing from those of $T$. australis $(8 \mathrm{~m}+2 \mathrm{sm}+2 \mathrm{st})$, T. bullocki $(7 \mathrm{~m}+3 \mathrm{sm}+3 \mathrm{st})$, and

TABLE 1. Measurement ( $\mathrm{mm}$ ) of the Telmatobufo ignotus tadpoles from Los Queules National Reserve (Mean \pm standard deviation). Number of replicates in bracket. Abbreviations as given in material and methods.

TABla 1: Medidas (mm) de las larvas de Telmatobufo ignotus de la Reserva Nacional Los Queules (Media \pm desviación típica). Número de réplicas entre paréntesis. Abreviaciones como las indicadas en material y métodos.

\begin{tabular}{lccccc}
\hline $\begin{array}{lcccc}\text { stages } \\
\text { characters }\end{array}$ & $\mathbf{2 5} \mathbf{( 2 )}$ & $\mathbf{3 4}(\mathbf{1})$ & $\mathbf{3 5} \mathbf{( 3 )}$ & $\mathbf{3 6} \mathbf{( 3 )}$ & $\mathbf{3 7} \mathbf{( 2 )}$ \\
\hline TL & $41.95-41.10$ & 64.40 & $64.93 \pm 3.98$ & $69.35 \pm 4.51$ & $75.20-73.90$ \\
BL & $17.55-18.40$ & 27.80 & $28.33 \pm 1.46$ & $36.23 \pm 3.66$ & $33.20-35.60$ \\
BW & $7.25-7.65$ & 12.20 & $10.40 \pm 0.85$ & $13.77 \pm 4.55$ & $11.80-18.55$ \\
MTW & $6.95-7.60$ & 12.30 & $11.97 \pm 1.97$ & $11.72 \pm 3.01$ & $13.60-8.35$ \\
SED & $7.10-6.15$ & 11.90 & $11.13 \pm 1.27$ & $12.23 \pm 0.84$ & $11.10-13.95$ \\
EDi & $1.70-1.80$ & 2.00 & $2.63 \pm 0.49$ & $4.03 \pm 2.06$ & $2.30-6.35$ \\
ODW & $7.25-8.00$ & 13.80 & $11.47 \pm 1.93$ & $9.87 \pm 5.91$ & $13.50-15.55$ \\
\hline
\end{tabular}

TABLE 2: Comparative morphometrics of tadpoles in similar Gosner`s stage of four species of Telmatobufo.

TABLA 2: Morfometrìa comparativa de larvas en similar estado de Gosner de las cuatro especies de Telmatobufo.

\begin{tabular}{lcccc}
\hline & T. australis & T. bullocki & \multicolumn{1}{c}{ T. ignotus } & \multicolumn{1}{c}{ T. venustus } \\
\hline Characteristics & Stage 29(3) & Stage 26(2) & Stage 26 (14) & Stage 27 (2) \\
\hline TL & 38.00 & $35.3 \pm 2.08$ & $48.93 \pm 4.96$ & $43.05 \pm 51.00$ \\
BL & 16.00 & $15.5 \pm 0.86$ & $21.56 \pm 2.93$ & $20.70 \pm 20.00$ \\
BH & 7.00 & $5.7 \pm 0.25$ & $9.93 \pm 3.20$ & $6.25 \pm 8.80$ \\
FH & 6.70 & $7.8 \pm 0.05$ & $8.00 \pm 1.23$ & $7.10 \pm 8.70$ \\
SED & 5.50 & $4.7 \pm 0.15$ & $8.16 \pm 1.27$ & $5.00 \pm 6.10$ \\
SND & 3.00 & $2.8 \pm 6.70$ & $3.95 \pm 1.36$ & $3.80 \pm 4.00$ \\
EDi & 1.40 & $1.3 \pm 0.00$ & $2.34 \pm 1.77$ & $0.90 \pm 1.70$ \\
ODW & 8.80 & $7.1 \pm 0.36$ & $10.04 \pm 2.07$ & $9.40 \pm 11.40$ \\
\hline
\end{tabular}




\section{T. venustus $(7 \mathrm{~m}+3 \mathrm{sm}+3 \mathrm{st})$ (Formas \& Cuevas 2000).}

DesCription of the Holotype Mature adult male (Fig. 1). Morphometric measurements are: SVL $70 \mathrm{~mm}$, HL 23.4 mm, HW $25.25 \mathrm{~mm}$, IDi $6.25 \mathrm{~mm}$, ED $6.35 \mathrm{~mm}$, ThL 36.8 $\mathrm{mm}$, TL $30.30 \mathrm{~mm}$, FL $50.75 \mathrm{~mm}$.

Head 1.2 times wider than long, and 2.77 times the snout vent length distance. Canthus rostralis slightly distinct, loreal region plane in frontal view. Lips thick. Low lip with a neckline in the half. Superior lip slightly concave in the half. Mouth reaches the first part (1/3) of the parotids in lateral and vertical view. Parotids ovoid, medians in size $(7.27 \mathrm{~mm})$ (clearly smaller than antero-posterior ocular globe diameter) and longitudinally located (Fig. 3b). Tympanum absent. Tongue rounded free behind. Snout rounded in dorsal view, slightly truncated in lateral profile (Fig. 3b). The anterior part of the throat presents a file of small thorns following the internal border of the inferior lips. Nostrils slightly ovoid, fringed and the inter-narial distance 1.2 times the inter-orbital distance. Inter-narial region slightly concave. Nostrils nearer to snout terminus than anterior part of the eyes (Fig. 1b). Moderate amount of warts (15), but numerous small spines below the parotids at the end of the mandible (Fig. 3b). Two slight orange-yellowish spots over the ocular globes are present; they are joined by an inter-orbital orange area. The same orange yellowish colour is noted on the arms proximally to the body, and also ventrally in the forearms (Fig. 1b). Body skin free. Forelimbs well developed. Tarsal fold thin, extending $85 \%$ of tarsus length, confluent distally with the fringe along inner margin of Toe I. Fingers thin, shorts and possessing whitish and rounded points (Fig. 1a). First finger with a patch of spines on it. Relative lengths of fingers: III $>$ IV $>$ II $>$ I (Fig. 3a, c). Feet with a wide inter digital webbing. Webbing formula: I $13 / 4-1$ 3/4 II 3/4-1 3/4 III 3/4-1 3/4 IV 3/4-1 3/4 V. Toes thins, slender and with single whitish rounded points. Relative lengths of toes: IV $>$ III $>$ V $>$ II $>$ I (Fig. 3 a, d). Well developed post femoral cutaneous fringe and gross tarsal fold present (Fig. 3a). Dorsum brown in colour, with orange cooperish hints near the head; possessing moderate darker warts with almost imperceptible yellowish reticulations among them. Belly greyish with yellowish irregular's minutes spot, extending on the ventral part of the arms, thighs and feet.

Female: unknown.

Tadpole (Stage 36): Lateral view (Fig. 4a): Tip of the snout blunt. Inter-narial distance minor than inter-ocular one $(0.8$ times). Body ovoid, approximately 0.8 times the tail length, and 2.6 longer than deep. Nostril, small dorso-lateral in position closer to the eyes $(5.0 \mathrm{~mm})$ than to the snout tip (7.5 $\mathrm{mm}$ ). Eyes rounded, small, antero-dorso-laterally oriented, located in the first third of the head. Spiracle sinistral, distal extreme with $2 \mathrm{~mm}$ free from the body; located on the inferior half of the body directed up and backward $\left(40^{\circ}\right)$ and nearer the body end than the tip of the snout. Oral disc extended to eye position in lateral view. Tail muscle is robust; musculature segmentation is visible from the end of the body backward. Fin tale symmetrical and present only in the last third of total length of the tadpole. Tail tip lanceolate, slightly rounded, paddle-shaped caudal fin. Anal fold is extended under tail muscle. Dorsal view (Fig. $4 \mathrm{~b})$ : Anterior portion of the head blade shaped, wider in the anterior than posterior part. Anterior part of the oral disc visible in dorsal profile. The inter-ocular distance is longer than inter-narial separation. Altogether the head and body present an oval shape with maximum width in the anterior part. Tail muscle starts in the first half of the body. Dorsal fin begins in the first half of the tail and represents $1 / 3$ the total tadpole length. Oral disc details (Fig. 4c): Oral disc wide, with sucks in form, and two rows of papillae on the anterior labium (AL), and papillae in random distribution on the posterior labium (PL), each of them with minute dark spot of pigmentation. In the commissures only the external row is presented. The upper rows of teeth reach the commissures. Oral disc is emarginated. Mandibles strong, crescent shaped, and internal borders smooth. Each mandible possesses long and thin teeth at the base. Tooth bilaterally located and decreases in size towards the centre. Tooth formula (2)/(1-1) (2). The inner row of teeth of the posterior labium presents a gap in the half that coincides with the vertices of the inferior mandible. Ventral region (Fig. 4d): Body opaque and prolonged backward in a sheath of skin that also covers the minute hind limbs. Two muscular cords with evident transverse stretch marks. Anal overture is dextral. Anal fold completely sticks to the tail muscle. Segmentation of tail muscle visible.

Colour in formalin. Ocular globe transparent and prominent, black pupils and white irises. Ventral region of the body whitish with orange irregular spot. Dorsum brown, with minute dark orange irregular, dark guanophores spots, and orange-reddish spots which are less abundant towards the tail. Ventral region presents two white cordons, which start after the oral disc and extend backward converging in the whitish anal sheath. Tadpole staging and measurements are presented in Table 1.

\section{STANDARD KARYOTYPE}

The karyotype of T. ignotus from the Los Queules National Reserve showed 26 chromosomes, each of them biarmed. Based on their relative length, pairs 1-5 were large (> 100 units), pair 6 was intermediate (among 80 to 100 units), and pairs 7 to 13 were small ( $<80$ units). Chromosome pairs 1 , 7, 8, and 10-13 were metacentrics, pairs 2, 4, 6 and 9 were submetacentrics and pairs 3 and 5 were subtelocentrics (Fig. 5). A secondary constriction was detected on the short arm of pair 5. A large difference in size between pairs 6 and 7 was observed. Measurements are presented 


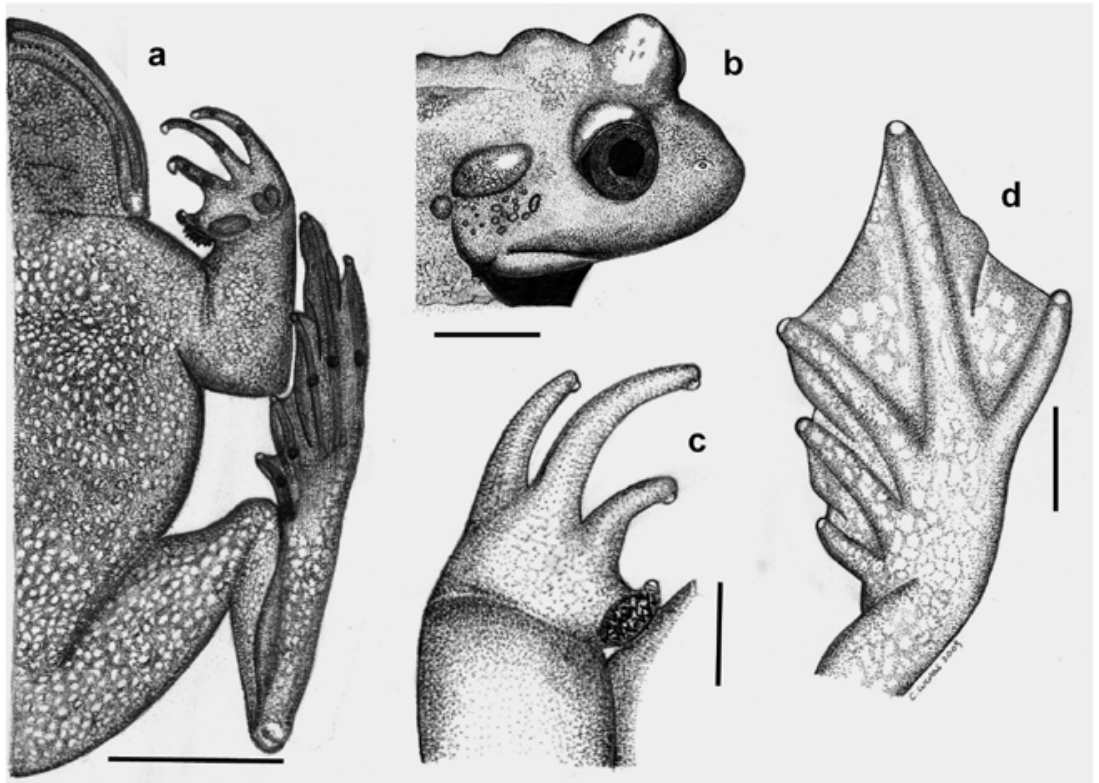

FIGURE 3. Morphological details of the adult of Telmatobufo ignotus, (a) Ventral view, (b) Lateral view of the head, (c) Left hand with sexual asperities, (d) Right foot with webbing. Bar in (a) $1.75 \mathrm{~cm}$, in (b), (c) and (d) $0.5 \mathrm{~cm}$.

Figura 3. Detalles morfológicos del adulto de Telmatobufo ignotus, (a) vista ventral, (b) vista lateral de la cabeza, (c) mano izquierda con asperezas sexuales, (d) pata izquierda con membranas. Barra en (a) $=1,75 \mathrm{~cm}$, en (b), (c), y (d) =0,5 cm.

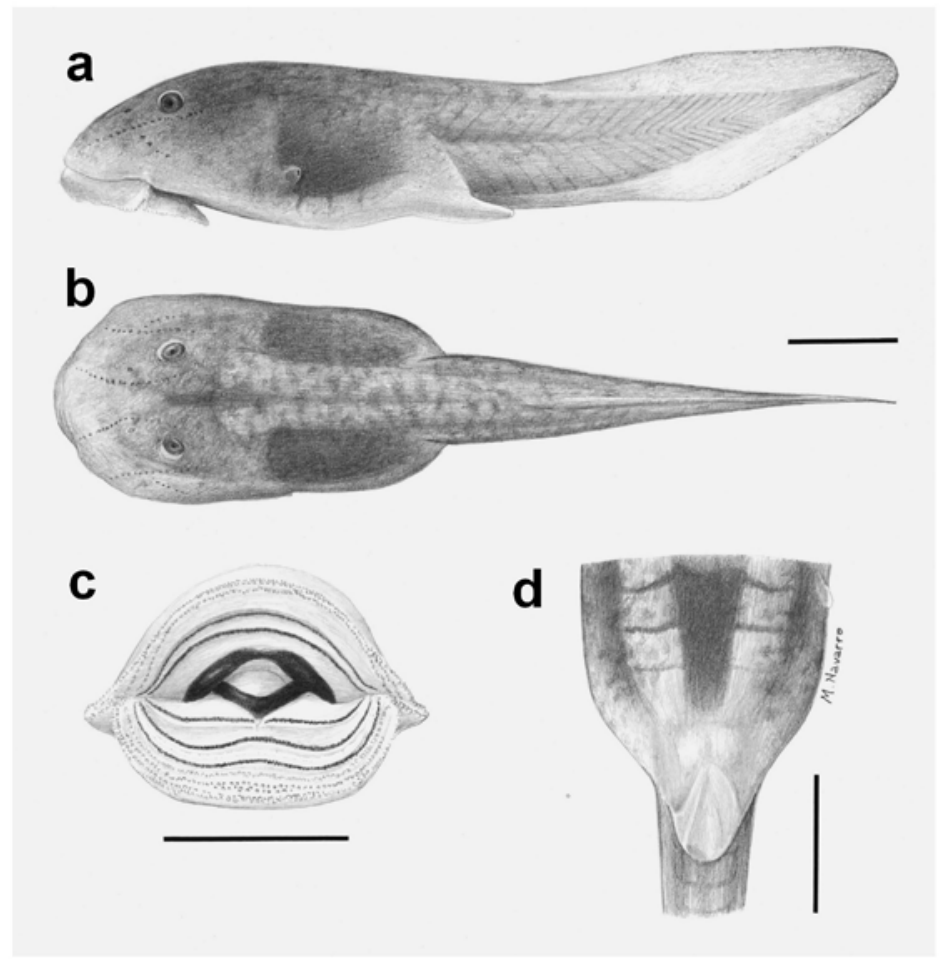

Figure 4. Tadpole of Telmatobufo ignotus from Los Queules, (a) Lateral view, (b) Dorsal view, (c) Oral disc details, (d) Ventral region. Bar equal $5 \mathrm{~mm}$.

FIGURA 4. Larvas de Telmatobufo ignotus de Los Queules, (a) Vista lateral, (b) Vista Dorsal, (c) Detalles del disco oral, (d) Regiòn ventral. Barra $=5 \mathrm{~mm}$. 


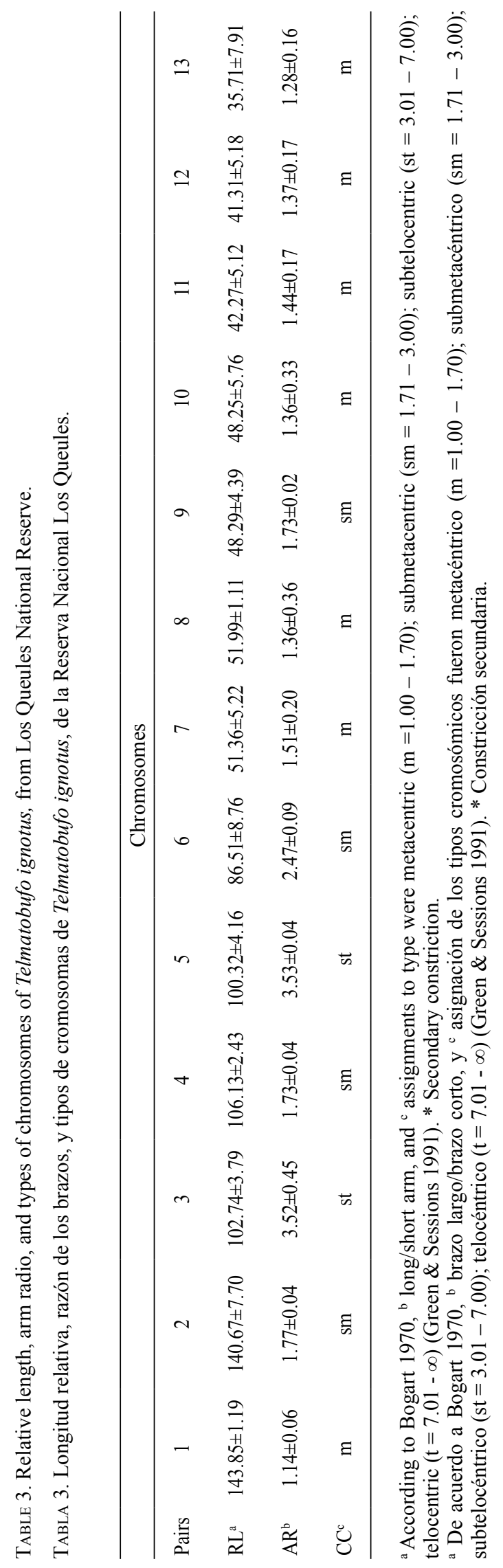




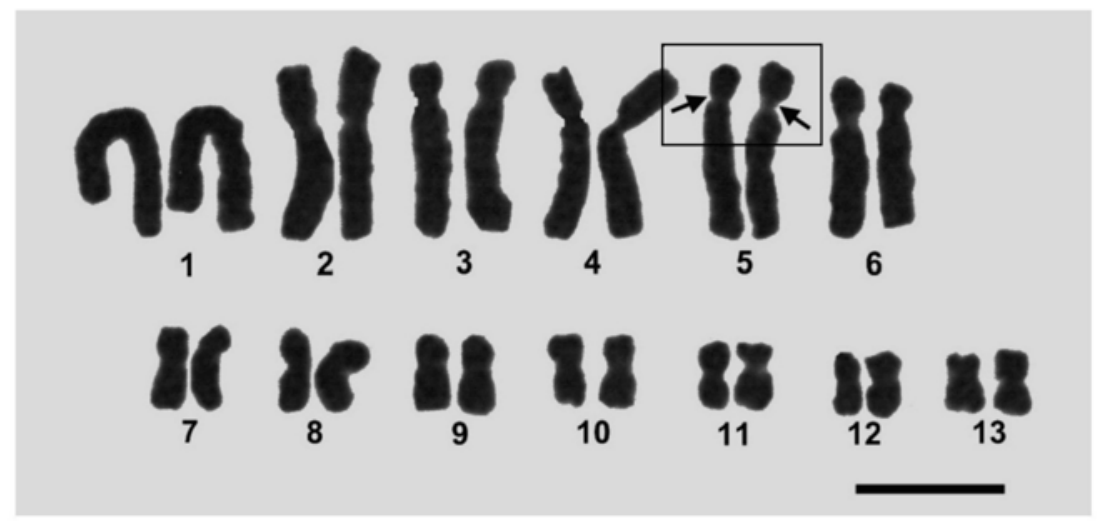

FIGURE 5. Standard karyotype of Telmatobufo ignotus. Arrows indicate secondary constrictions position. Bar $=10$ um.

Figura 5. Cariotipo estándar de Telmatobufo ignotus. La Flecha indica la posición de las constricciones secundarias. Barra $=10$ um.

in Table 3.

\section{Distribution AND Ecology}

The Maulino forest is located at the coastal range of southcentral Chile. These woody ecosystems have been severely disrupted by intense human activity and at present, the landscape is dominated by large extensions of Monterrey pine (Pinus radiata) cultures, where scarce remnants of native forest persist (Bustamante $\&$ Simonetti 2005). The new collection site is located within a remnant of the Maulino forest dominated by Nothofagus alessandrii (Ruil) and Gomoterga queule (Queule). The National Reserve Los Queules is a small area of 147 ha inserted in a matrix of Pinus radiata and Eucalyptus globulus. Weather data were collected at Chanco station near of Los Queules National Reserve. From 2003 to 2006, mean annual rainfall was $857 \mathrm{~mm}$.

Both, the adult and the juvenile of Telmatobufo ignotus were collected during the austral autumn under rocks at the border of the stream Ramadillas in the year 2009, which has a maximum wide of $5 \mathrm{~m}$. The juvenile was more vivid coloured with orange and yellowish tints over a brown colour and was $40-50 \mathrm{~mm}$ in large. Both specimens were kept in a cooler where the juvenile was eaten by the adult during the night (cannibalism). A froglet was collected in the middle of May 2008 at the border of the same stream. Tadpoles of T. ignotus were collected during the summer season (December to February 2007 and 2008) in the same place. Eupsophus septentrionalis Ibarra-Vidal, Ortiz \& Torres-Pèrez 2004 and Alsodes sp. are species of frogs that also occur in this locality but the tadpoles of these species differs from Telmatobufo larvae in their size (i.e. $25 \mathrm{~mm}$ in Eupsophus queulensis, $44 \mathrm{~mm}$ in Alsodes sp., $75 \mathrm{~mm}$ in $T$. ignotus).

Etimology The name ignotus is a Latin adjective and refers to the fact that this species during long time remaining in the anonymity and ignored.

\section{DISCUSSION}

Schmidt (1952), and Formas et al. (2001) suggested that the following presumptive morphological synapomorphies may support the genus Telmatobufo: 1) Larger sized animals $(60.4-83.0 \mathrm{~mm})$ with bufoniform aspect; 2) parotid glandules present; 3) humeral glandule well marked; 4) well developed foot webbing; 5) wide xiphisternum; 6) stream mountain tadpole with mouth-like sucker in form, 7) strong and wide tail; and 8) 26 chromosomes (Formas \& Cuevas 2000). The new frog material collected is considered to be a member of Telmatobufo because it has at least seven of the eight aforementioned characters; although, its distribution at National Reserve Los Queules precludes for the species' inclusion in Telmatobufo, this is cited as a new record for the genus herein.

Concerning the specific status, at first sight the adult morphological appearance of Telmatobufo from Los Queules (brown with orange-yellowish spot over the eyes, and an orange area between ocular globes) resemble $T$. bullocki from Nahuelbuta Range (sensu Schmidt 1952), however, other morphologic details observed in the adult, tadpoles and chromosomes (see comparison section) drive to propose a new morphological species hypothesis herein: Telmatobufo 
ignotus sp. nov.. Furthermore, results on chromosome gross morphology of the specimens from Los Queules showed some auto-apomorphic attributes, such as its chromosome formula, and secondary constriction position. Actually, in the karyotype of new specimens from Los Queules, a single secondary constriction is present on the short arm of pair 5 (st). In each of the other three species, a secondary constriction occurs on the short arm of pair 12. In T. australis and $T$. venustus, an additional secondary constriction also occurs on the short arm the pair 6. Formas \& Cuevas (2000) proposed the number of secondary constrictions as specific markers to the genus. Thus, chromosomal characteristics distinguish the specimens from Los Queules and the specimens of T. bullocki from Nahuelbuta Range. Further analyses (e.g. chromosome banding and ADN sequences) will added more evidences to support the specific taxonomic status of the new species from Los Queules.

Telmatobufo ignotus occurs only in his type locality, being this place the more septentrional distribution in the coastal range brought for Telmatobufo until now. Recently, Donoso et al. (2010) determined as member of T. bullocki two specimens detected in Los Queules Reserve (type locality of T. ignotus). However, their conclusion is supported on two weak arguments; a) The examination of a female specimen (not specified by the authors), being males characters more important in Telmatobufo species determination (Formas et al. 2001); and b) A comparison of the 16s ribosomal mtDNA sequence between the specimen from Los Queules and $T$. bullocki from Caramavida River, being also this argument controversial since this molecular marker has been suggested just as a complement of the COI (Cytochrome oxidase I) in vertebrates DNA bar-coding (Vences et al. 2005). Moreover, this approach has not yet been implemented in Chilean anurans and its reliability is widely debated at present. Based on these arguments, that specimen is primarily suggested as a member of T. ignotus herein. These new data extend the northern distribution of Telmatobufo in $50 \mathrm{~km}$ from Quirihue (Escobar et al. 2005) and $200 \mathrm{~km}$ from the Mountain range of Nahuelbuta (Ramadillas), being both localities the most recent records known for the genus (Cuevas \& Cifuentes 2009). However, because the geographical notes published by Escobar et al. (2005) were not accompanied by a morphological description or photography of the animals detected, at the light of the new species description, the taxonomic status of that material will remain undetermined, until a detailed examination of an adult specimen, since it might correspond to another locality of $T$. ignotus.

The taxonomic status of the previously knew species of Telmatobufo (T. australis, T. bullocki and T. venustus) has been well established (Formas et al. 2001). Nevertheless its phylogenetic relationships have been recently revised (Frost el al. 2006). For a long time Telmatobufo remained grouped in the tribe Calyptocephalellinii of the family Leptodactylidae beside Caudiverbera (Lynch 1978). But recently, Frost (2009) "upgraded" the tribe status to Calyptocephalellidae to imbed Telmatobufo and Caudiverbera; following chromosomal arguments given by Formas \& Espinoza (1975), Córdova \& Descailleaux (2005) which suggest that Batracophrynus is not phylogenetically close to Caudiverbera and discarding Batracophrynidae (Batracophrynus, Caudiverbera, Telmatobufo) sensu Frost et al. (2006). The present hypothesis of classification (Calyptocephalellidae) agree with San Mauro et al. (2005) whom suggest 120 my of a split of Calyptocephalella from Australian Myiobatrachids. San Mauro et al. (2005) also suggest that the current presence of Calyptocephalella (= Caudiverbera) restricted to geographic refuges indicates "that these early neobatrachians may have been more widespread but were outcompeted by the more modern hyloid and ranoid radiations in large parts of their original distribution area". The occurrence of Telmatobufo (a member of Calyptocephalellidae) in Los Queules agrees with this biogeographic hypothesis. The wider Telmatobufo dispersion in coastal range could be explained by the association of this ancient fauna with a broad distribution of Nothofagus forest towards the north (Caudiverbera reach the $32^{\circ} \mathrm{LS}$ in their northern range), which could have provided refuge for the amphibians during the height of glaciations in the south of Patagonia (Vuilleumier 1968).

Nowadays, the global amphibian declining is a well-known issue (Beebee \& Griffith 2005) and has been attributed to several causes, especially habitat loss and disease. Becker et al. (2007), identified a further factor, namely "habitat split" (defined as human-induced disconnection between habitats used by different life history stages of a species) which forces forest-associated amphibians with aquatic larvae to make risky breeding migrations between suitable aquatic and terrestrial habitats. The habitats of the Chilean frogs such as the Chilean winter Valdivian rainy forest have suffered a rapid deterioration in the last 30 years. Because of the loss of at least $70 \%$ of plants species and the increasing menace experienced by its fauna (including frog species), this ecosystem is considered one of 25 planet's diversity hotspot (Conservation International 2007). Unfortunately scarce knowledge exists concerning the adaptation of amphibians to this new distressing habitat status (Bustamante \& Simonetti 2005, Cuevas \& Cifuentes 2009). According to Formas et al. (2001) specimens of Telmatobufo were collected at the border of a road (under a rock), and Escobar et al. (2005) detected specimens within a plantation of Pinus radiata, 90 meters distant from native forest. This suggests a wide home range to these species and a series of additional problems distressing them, such as, border effect and refuge loss. Furthermore, Telmatobufo species possess a free life tadpole of mountain stream environment, with a mouth- 
like sucker (Formas et al. 2001, Cuevas \& Cifuentes 2009), implying that larvae develop preferably in streams with big stone substratum (Ortiz \& Ibarra-Vidal, 2005) and very strong water flowing, where they stay on at least two years before reaching the metamorphosis. This life strategy makes it a very vulnerable species (Formas et al. 2001, Cuevas $\&$ Cifuentes 2009). Conservation efforts until now have been focused in more emblematic species like Rhinoderma darwinii or Rhinoderma rufum, leaving other species without awareness. The type locality of Telmatobufo ignotus is a very small remnant of Maulino forest, and constitutes an immersed island in a matrix of Pinus and Eucalyptus (Ortiz \& Ibarra-Vidal, 2005). The stream flowing through this remnant shows a high grade of sediment accumulation (dragged by the rain from nearby pines plantations), putting in danger the reproductive habitat of these animals and its viability as a species because of habitat split.

Taxonomy can have a profound and instant impact on conservation planning and decisions and may even be able to force some taxonomists to consider concealing locality data to prevent the exploitation of species habitat (Stuart et al., 2006). The new species described herein, is a new record within a National Reserve (SNASPE $=$ National Service of Wild Protected Areas of the State) for one of the more primitive Gondwanic genera of frog of South America. Considering the progressive habitat degradation and the fact that most of the Telmatobufo population occurs in unprotected areas, this information represent an important argument in support of protecting remnants of native forest in areas where this ecosystems has been seriously altered.

\section{ACKNOWLEDGEMENTS}

I am grateful to National Forestal Corporation for permission to collect in the Los Queules National Reserve. Fernando Campos kindly help us in the fieldwork and facilitate house commodities. Marcos Navarro drew Fig. 3 and Javiera Cuevas, Felipe Rabanal and José Nuñez help us during fieldwork. Marcos Navarro expertly drew the tadpole slide. This work was partially supported by an NSF-PIRE award (OISE 0530267) for collaborative Research on Patagonian Biodiversity granted to the following institutions: Brigham Young University, Centro Nacional Patagónico, Dalhousie University, Instituto Botánico Darwinion, Universidad Austral de Chile, Universidad Nacional del Comahue, Universidad de Concepcion and University of Nebraska.

\section{BIBLIOGRAPHY}

Altig, R. 2007. A primer for the morphology of anuran tadpoles. Herpetological conservation and biology 2(1): 71-74.

Altig, R., \& Johnson G.F. 1989. Guilds of anuran larvae: relationships among developmental modes, morphologies, and habitats. Herpetological monographs 3: 81-109.

Beebee, T.J.C., \& Griffiths R.A. 2005. The amphibian decline crisis: A watershed for conservation biology? Biological Conservation 25(2): 271-285.

Becker, C.G., Fonseca, R., Haddad, C.F.P., Batista, R.F., Prado, P.I. 2007. Habitat Split and the Global Decline of Amphibians. Science 318: 1775-1777.

Bogart, J.P. 1970. Systematic problems in the amphibian family Leptodactylidae (Anura) as indicated by karyotypic analysis. Cytogenetics 9(5): 369-383.

Bustamante, R.o., \& Simonetti J.A. 2005. Is Pinus radiata invading the native vegetation in central Chile? Demographic responses in a fragmented forest. Biological Invasions 7(2): 243-249.

Conservation International. 2007. An online reference forests/ Pages/default.aspx [accessed 23 February 2010].

Córdova, J. H., \& Descailleaux J. 2005. El análisis cladístico preliminar de los cariotipos de cinco especies de Telmatobius y dos de Batrachophrynus no apoya su separación genérica. In: Estudios sobre las ranas andinas de los géneros Telmatobius y Batrachophrynus (Anura: Leptodactylidae) (eds. Lavilla, E. O., I. De la Riva, E. Font \& J. Lluch), pp. 187-218. Monografías de Herpetología Vol. 7, Asociación Herpetológica Española, Valencia.

Cuevas, C.C. \& Formas. J.R. 1996. Heteromorphic sex chromosomes in Eupsophus insularis (Amphibia: Anura: Leptodactylidae). Chromosome Research 4(6): 467-470.

Cuevas, C.C., \& Cifuentes S.L. 2009. Frogs and life strategies: an approaching to evaluate forest ecosystem in southern Chile. In: Ecological advances in Temperates forest (ed. Oyarzùn C. \& Staelens Y.), pp. 17-30. Elsevier Press, Belgian.

Dayrat, B. 2005. Towards integrative taxonomy. Biological Journal of the Linnean Society 85: 407-415.

Diaz, N., Sallaberry, M. \& H. NúÑEz. 1983. The tadpole of Telmatobufo venustus (Anura: Leptodactylidae) with a consideration of generic relationships. Herpetologica 39(2): 111-113.

Donoso, D.S., Correa C., Henrriquez P., Lagos N.F., Mendez M.A. 2010. Amphibia, Anura, Calyptocephalellidae, Telmatobufo bullocki Schmidt, 1952: Distribution extension, habitat use and geographic distribution map. ChekList 6: 298-300.

Escobar, M.A.H., Estades C.F., Falcy M. \& Vukasovic M.A. 2005. Geographic distribution. Telmatobufo bullocki (Bullock's Frog). Herpetological Review 36(1): 77.

Formas, J.R. 1972. New observations of Telmatobufo australis Journal of Herpetology 66(1): 1-3.

FormAs, J.R. \& ESPINOZA N.D. 1975. Karyological relationships of frogs of the genus Telmatobufo (Anura: Leptodactylidae). Herpertologica 31: 429-432.

Formas, J.R. 1979. Los anfibios anuros del bosque temperado austral de Sudamérica. In: The South American Herpetofauna: its origin, evolution and dispersal (ed. E.W. Duellman), pp. 341-369. Monograph of the Museum of Natural History of the University of Kansas.

Formas, J.R. 1988. The tadpole of Telmatobufo bullocki (Anura: Leptodactylidae). Herpetologica 44(4): 458-460.

Formas, J.R. 1995. Anfibios. In: Diversidad biológica de Chile (Eds. Simonetti J.A., Arroyo M.T.K., Spotorno A.E. \& E. Lozada), pp. 314-325. Comisión Nacional de Investigación Científica y Tecnológica, Santiago, Chile.

Formas, J.R. \& Cuevas C.C. 2000. Comparative cytogenetics analyses of Telmatobufo genus. Proceedings of the Biological society of Washington 113 (4): 890-899. 
Formas, J.R., NúÑEZ, J.J. \& BRIEVA L.M. 2001. Osteología, taxonomía y relaciones filogenéticas de las ranas del género Telmatobufo (Leptodactylidae) Revista Chilena de Historia Natural 74(2): 365-387

Frost, D.R., Grant, T., Faivovich. J., Bain, R.H., HaAs, A., Haddad, C.F.B., De Sá R.O., Channing, A., Wilkinson, M., Donnellan, S.C., Raxworthy, C.J., Cambell, J.A., Blotto B.L., Moller P., Drewes R.C., Nussbaum R.A., LynCh J.D, Green D.M., Wheeler W.C. 2006. The amphibian tree of life. Bulletin of the American Museum of Natural History 297: 3-370.

Frost, D.R. 2009. Amphibian species of the world: an online reference. Version 5.3 (05 Septiembre, 2009). http:// research.amnh.org/herpetology/amphibia/index.php.

GreEn, D.M. \& SESSIONS S.K. 1991. Nomenclature for chromosomes. In: Amphibian Cytogenetics and Evolution (Eds. Green, D.M. \& S.K. Sessions), pp. 431-432. Academic Press, San Diego, USA.

Gosner, K.L. 1960. A simplified table for staging Anuran embryos and larvae with notes on identification. Herpetologica 16(3): 183-190.

Ibarra-VIDAl, H., Ortiz, J.C. \& Torres-Perez, F. 2004. Eupsophus septentrionalis $\mathrm{n}$. $\mathrm{sp}$. nueva especie de Leptodactylidae (AMPHIBIA) de Chile Central. Boletin Sociedad de Biologia de Concepcion 75: 91-102.

IuCN, Conservation International, and NatureServe. 2008. An Analysis of Amphibians on the 2008 IUCN Red List $<$ www.iucnredlist.org/amphibians $>$. Downloaded on 6 October 2008.

LyNCH, M.J.D. 1978. A re-assessment of the Telmatobiine Leptodactylid frog of Patagonia. Museum of Natural History, University of Kansas, Lawrence, Kansas 72: 157.

Myers, C. \& Duellman, W.E. 1982. A new species of Hyla from Cerro Colorado, and other tree frog records and geographical notes from western Panama. American Museum of Natural History 2752:1-32.

NúÑEZ, J. \& J.R. FoRMAS. 2000. Evolutionary history of the Chilean frog genus Telmatobufo (Leptodactylidae): an immunological approach. Amphibia-Reptilia 21(3): 351356.

Ortiz, J.C. \& DíAz-PÁEz H. 2006. Estado de conocimiento de los anfibios de Chile. Gayana (Zoología) 70(1): 114-121.

Ortiz, J.C. \& IbarRa-Vidal H. 2005. Anfibios y reptiles de la cordillera de Nahuelbuta. En: Historia, Biodiversidad y Ecología de los Bosques Costeros de Chile. (Eds. Smith-
Ramirez C, J.J. Armesto \& C. Valdovinos), pp. 427-440. Editorial Universitaria, Santiago, Chile.

Pefaur, J. 1971. Nota sobre Telmatobufo bullocki Schmidt (Anura: Letodactylidae). Boletín del Museo Nacional de Historia Natural Chile 32: 215-225.

PhiLIPPI, R.A. 1899. Descripciones breves de dos especies nuevas de sapo (Bufo). Anales Universidad de Chile 104: 723725.

San Mauro, D., Vences, M., Alcobendas, M. Zardoya, R. \& MEYER A. 2005. Initial diversification of living amphibians predated the breakup of Pangaea. American Naturalist 165: 590-599.

SAVAGe, J.M., \& HeYer, W.R. 1967. Variation and distribution in the tree frog genus Phyllomedusa in Costa Rica, Central America. Beiträge zur Neotropischen Fauna 2:111-131.

Schmid, M. 1978. Chromosome banding in Amphibia I. Constitutive heterochromatin and nucleolus organizer regions in Bufoand Hyla. Chromosoma, 66: 361-388.

Schmid, K.P. 1952. A new leptodactylid frog from Chile. Fieldiana Zoology 34(2): 11-15.

Stuart B.L., Inger R.F., Voris H.K. 2006. High level of cryptic species diversity revealed by sympatric lineages of Southeast Asian forest frogs. Biological Letters 2:470474.

Vences, M., Thomas, M., Bonett, R.M. Vieites D.R. 2005. Deciphering amphibian biodiversity through DNA barcoding: chances and challenges. Philosophical transactions of the Royal Society 360: 1859-1868.

Vuilleumier, F. 1968. Origin of frogs of Patagonian forest. Nature 219: 87-89.

Wiens, J.J. 1993. Systematic of the Leptodactylid frog genus Telmatobius in the Andes of Northern Perú. Occasional Paper Museum Natural History University of Kansas 162:1-76.

\section{Examined material}

Telmatobufo australis (1 adult male) San Pablo de Tregua, Panguipulli.

Telmatobufo australis (3 tadpoles) Chaiguin, Corral.

Telmatobufo bullocki (1 adult female). El Vergel, Angol.

Telmatobufo venustus (1 adult male). Altos de Vilches, Talca.

Telmatobufo venustus (1 tadpole). Altos de Vilches, Talca.

Recibido: 08.09.09

Aceptado: 05.07.10 